\title{
English for the Beginners di Era New Normal melalui Joyful Learning di SDI Turekisa, Ngada-Flores, NTT
}

\author{
Agustina Pali ${ }^{1}$, Finsensius Mbabho' ${ }^{2}$ Marselina Wali ${ }^{3}$ \\ ${ }^{1,2,3}$ Pendidikan Guru Sekolah Dasar, Fakultas Keguruan dan Ilmu Pendidikan, Universitas Flores \\ indahpali2020@gmail.com
}

\begin{abstract}
ABSTRAK
Dunia pendidikan seolah-olah "mati suri" di tengah-tengah bergejolaknya wabah covid-19. Hal ini berdampak pada menurunnya minat belajar bahasa Inggris bagi para pembelajar pemula (English for the beginners) di SDI Turekisa, Kabupaten Ngada, Flores-NTT. Kegiatan ini melibatkan English for the beginners di SDI Turekisa dengan rata-rata usia 10-11 tahun melalui metode joyful learning. Hasil dari kegiatan ini memberikan dampak yang positif terhadap minat belajar dan peningkatan English skills bagi para peserta kegiatan. Untuk itu, kegiatan English for the Beginners di era new normal melalui metode Joyful Learning dengan beberapa teknik pendekatan antara lain ceramah interaktif, songs and games, drilling dan demonstrasi dapat dijadikan pilihan alternative dalam kegiatan ini untuk mengembalikan mood belajar siswa yang terlanjur "mati suri".
\end{abstract}

Kata kunci: English for the Beginners, New Normal, Joyful Learning

\section{ABSTRACT}

The world of education seems to be "suspended animation" in the midst of the turmoil of the Covid-19 outbreak. This has an impact on decreasing interest in learning English for beginner learners at SDI Turekisa, Ngada Regency, Flores-NTT. This activity involves beginner learners at SDI Turekisa with an average age of 10-11 years by using the joyful learning method. The results of this activity had a positive impact on interest in learning and increased English skills for the participants. For this reason, the English for the beginners activity in the new normal era through Joyful Learning method with several approach techniques including interactive lectures, songs and games, drilling and demonstrations are used as alternative options in this activity to restore the learning mood of students who have already "suspended animation".

Keywords: English for the Beginners, New Normal, Joyful Learning

\section{PENDAHULUAN}

Pandemi covid-19 yang melanda dunia akhir-akhir ini menjadi momok yang cukup menakutkan. Hal ini berimbas pada berbagai lini kehidupan, salah satunya pada sector pendidikan di Indonesia. Dunia pendidikan seolah-olah "mati suri" di tengah-tengah bergejolaknya wabah ini. Banyak pro dan kontra yang terjadi tentang jalan keluar yang telah diambil oleh pemerintah melalui kemendikbud saat ini. Di luar perdebatanperdebatan yang terus mengalir ini, satu hal yang tidak boleh diabaikan adalah sebuah prinsip bahwa kegiatan pembelajaran tidak boleh stagnan melainkan harus tetap survive. Kesurvivevan ini dapat dibuktikan melalui pembelajaran yang terus berlanjut di masa kenormalan baru (new normal era).

Pembelajaran di new normal era memiliki tantangannya tersendiri. Tantangan yang tentu berbeda dari era sebelumnya, (Karalis, 2020),
(Tria, 2020). Untuk itu, para pemerhati pendidikan secara otomatis pun tertantang untuk melakukan aktivitas-aktivitas pembelajaran yang membantu siswa untuk lebih survive dan melupakan sejenak momok pandemic saat ini, (Crawford et al., 2020), (Cahapay, 2020).

Pembelajaran yang dirancang di era ini pun diharapkan lebih memiliki nilai plus jika dibandingkan dengan era sebelumnya. Apalagi pembelajaran pada dunia anak. Dunia anak identik dengan dengan dunia yang menyenangkan (fun). Rancangan pembelajaran yang digunakan pun tentunya harus menyenangkan, (Pali \& Ota, 2020), (Wijoyo \& Indrawan, 2020), (Pujaningsih, Damayanti, 2020). Salah satu pendekatan pembelajaran bermakna dan menyenangkan dalam dunia anak adalah joyful learning. Joyful learning dipilih karena pendekatan ini lebih mementingkan kenyamanan siswa dalam proses pembelajaran. Joyful Learning are active learning 
strategy, a concept and practice of synergic learning of meaningful learning, (Anggoro et al., 2017), (Proity, 2015), (Fisher et al., 2015). Dapat dikatakan pula bahwa joyful learning memberi ruang bagi para pembelajar untuk mengekpresikan diri dalam aktivitas-aktivitas pembelajaran yang memberikan makna tersendiri bagi mereka. Joyful learning dapat menghindari rasa tertekan selama pembelajaran berlangsung.

Joyful learning yang dilaksanakan dalam kegiatan ini adalah Joyful learning pada English for the Begginers di SDI Turekisa, Bajawa, Flores. Subjek ini dipilih karena siswa/I di SDI Turekisa pun merasakan dampak dari pandemic covid-19 ini. Dampak yang sangat terlihat adalah semangat belajarnya yang menurun karena cukup lama mereka "dirumahkan". Aktivitas belajar dari rumah cukup membuat mereka merasakan kejenuhan dan juga membosankan. Tidak terkeculai dalam pembelajaran Bahasa Inggris. Untuk itu, kegiatan English for the Begginers di Era New Normal melalui Joyful Learning ini dapat dijadikan pilihan alternative untuk mengembalikan mood belajar siswa yang terlanjur "mati suri".

Kegiatan ini bertujuan untuk mengembalikan minat belajar bahasa Inggris para pembelajar pemula (English for the beginners) di SDI Turekisa dengan rata-rata usia 10-11 tahun. Para pembelajar pemula bahasa Inggris yang berusia 10-11 tahun memiliki cirri-ciri reciprocity, imajinatif dan aktif. Mereka menyukai belajar bahasa Inggris melalui permainan, cerita, maupun lagu. Hal pokok yang harus dipahami adalah belajar berbahasa sambil bermain adalah hal yang menyenangkan bagi mereka. Selain itu ciri khas mereka yang lain adalah belajar bahasa dengan cara melakukan sesuatu sambil beraktivitas (learning by doing), (Nurhadi, 2012), (Hasan et al., 2015). Dari ciri-ciri anak-anak ini dapat diketahui bahwa dunia belajar anak akan lebih penuh warna jika dilakukan melalui kegiatan belajar yang menyenangkan (joyful learning).

\section{METODE KEGIATAN}

Untuk menjawabi tujuan kegiatan dimaksud, maka metode yang digunakan adalah kegiatan English for the Beginners melalui joyful learning. Karena kegiatan ini dilaksanakan di era new normal, maka keterlibatan mitra pun dibatasi dengan jumlah peserta 15 orang. Kegiatan pendampingan ini melibatkan tiga orang tim dosen yang berkompetensi sebagai instruktur kegiatan. Secara umum, tahapan pengorganisasian kegiatan dapat dijelaskan sebagai berikut:

a. Tahapan Persiapan
Hal-hal yang dilakukan pada tahap ini adalah 1) membuat kesepakatan dengan pihak sekolah mengenai lokasi sasaran dan waktu pelaksanaan kegiatan, 2) melakukan interview orally pada peserta kegiatan untuk mengetahui pemahaman awal siswa akan dunia bahasa Inggris, 3) menyiapkan materi pendampingan English for the begginers, 4) menyiapkan media pendukung joyful learning, 5) menyiapkan angket respon siswa yang akan disebarkan pada akhir kegiatan, 6) Menyiapkan alat-alat pendukung protocol kesehatan pada pembelajaran di new normal era, misalnya masker, face shield, hand sanitizer, hand scull, dll.

b. Tahapan Pelaksanaan Pendampingan

Teknik yang digunakan dalam pelaksanaan pendampingan mengakomodir teknik-teknik dari joyful learning antara lain:

1) Teknik ceramah interaktif; ceramah interaktif dimaksudkan agar peserta mendapatkan pengetahuan yang berkaitan dengan bahasa Inggris untuk anak-anak (English for kids).

2) Song and Games Belajar melalui lagu dan permainan.

3) Teknik drill/ drilling; teknik ini menekankan pada pelaksanaan kegiatan latihan-latihan, (Sanatun, Sulisworo, 2017). Dalam kegiatan ini, drill/latihan secara khusus bertujuan untuk meningkatkan ketrampilan dalam mengucapkan (pronunciation) English Vocabulary, ketrampilan menulis, membaca dan juga mendengar.

4) Teknik demonstrasi; mendemonstrasikan kembali materi yang diajarkan berupa pengucapan English vocabularies, reading, writing, listening kata-kata sederhana yang berhubungan dengan dunia anak dan disesuaikan dengan level kemampuan berbahasa anak.

c. Tahapan Akhir

Target yang ingin dicapai dari kegiatan ini adalah untuk mengetahui sejauh mana efektifitas metode joyful learning dalam membangkitkan minat belajar English for Kids di New Normal era. Untuk itu disiapkan soal evaluasi akhir dan angket respon siswa yang berisikan sembilan butir pernyataan. Hasil test dan angket ini kemudian dianalisis untuk mencapai rata-rata dari setiap item pernyataan dengan merujuk pada criteria berikut: 
Tabel 1. Penilaian Test \& Angket Respon Siswa

\begin{tabular}{lll}
\hline No & Nilai (\%) & Kriteria \\
\hline 1 & $92-100$ & Sangat Baik \\
2 & $75-91$ & Baik \\
3 & $50-74$ & Cukup Baik \\
4 & $25-49$ & Kurang Baik \\
5 & $0-24$ & Tidak Baik \\
\hline
\end{tabular}

\section{HASIL \& PEMBAHASAN}

Kegiatan english for the beginners diawali dengan oral interview pada setiap peserta kegiatan. Point-point interview yang diajukan adalah yang berkaitan dengan minat belajar bahasa Inggris di new normal era dan problem riil yang dihadapi siswa. Hasil interview mengindikasikan bahwa situasi pembelajaran di era new normal (belajar dari rumah) menciptakan kejenuhan yang cukup tinggi. Hal ini berdampak pada minat belajar siswa dan pemahaman bahasa Inggris yang cukup rendah. Setelah menemukan akar permasalahan ini maka tim kegiatan merumuskan solusi permasalahan dengan harapan solusi-solusi ini dapat mengatasi problem riil yang dialami peserta. Jalan keluar yang disepakati adalah dengan melakukan kegiatan English for the beginners melalui joyful learning. Teknik-teknik pembelajaran yang menyenangkan ini diharapkan dapat mengembalikan minat belajar bahasa Inggris peserta.

Kegiatan English for the beginners yang dilaksanakan di era new normal ini dilaksanakan selama sepekan di aula kantor desa Turekisa. Kegiatannya meliputi outdoor dan indoor activity.

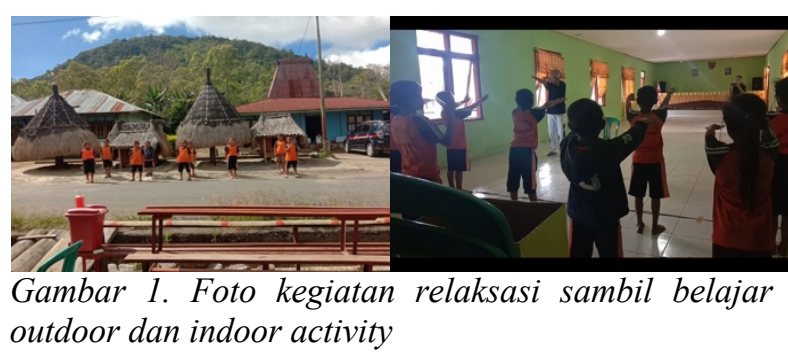

Kegiatan outdoor activity diawali dengan penerapan protocol kesehatan; mencuci tangan, penggunaan masker, face hield, hand sanitizer dan lain-lain. Outdoor activity bertujuan agar siswa dapat melakukan relaxasi sambil belajar bahasa Inggris di luar ruangan. Selain itu sengaja dilaksanakan untuk mendapatkan vitamin D dengan berjemur di bawah sinar matahari pagi.
Pada saat relaxasi siswa diarahkan untuk memperhatikan objek sederhana yang dapat dijangkau dengan panca indera mereka. Objekobjek tersebut kemudian dilist namanya dalam bahasa Indonesia. Setelah itu, siswa berdiskusi (indoor activity) untuk menemukan kata bahasa Inggris dari objek yang mereka temukan di luar ruangan. Kebanyakan dari mereka merasa malu dan kurang percaya diri untuk mengucapkan kata - kata sederhana tersebut dalam bahasa Inggris (English pronunciation). Untuk itu, tim kegiatan mencoba membangkitkan semangat belajar dan rasa percaya diri mereka dengan mengajarkan how to pronounce dan how to spelling melalui lagu dan permainan (songs and games). Materi pertama yang dipelajari adalah how to pronounce alphabet melalui alphabet songs.

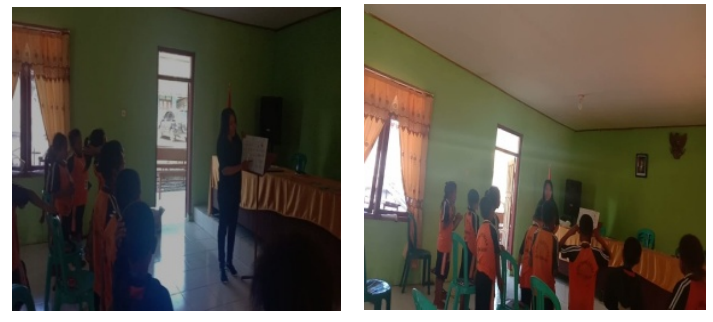

Gambar 2. Foto aktivitas Belajar Bahasa Inggris melalui Songs \& Games

Setelah mempelajari how to pronounce English alphabet, siswa diminta untuk melakukan spelling. Spelling yang dimaksudkan adalah spelling mengenai English vocabulary dari object yang mereka temukan pada saat outdoor activity. Ada banyak vocabulary yang didapat dari kegiatan relaksasi outdoor antara lain grass (green grass), rock, ground, sun, sky, (blue sky), house, friends, motorbikes, home, coconut trees, flowers, hills, road, field, flags, birds, chickens, dogs, buffalo, cow, water, buckets, soap, hand sanitizer, masks, tissues dan lain-lain. Setelah mempelajari how to spell, siswa diarahkan untuk melakukan drilling. Drilling dimaksudkan untuk meningkatkan kemampuan reading, writing, speaking dan listening mengenai vocabulary sederhana yang telah mereka pelajari.

Topik pembelajaran selanjutnya adalah greetings. Teknik yang digunakan dalam mempelajari greetings adalah demonstrasi dalam in-pair activity. Kegiatan ini sangat menyenangkan karena para peserta diberi kebebasan untuk memilih pasangan dan mempelajari greetings bersama pasangannya sebelum mereka mendemonstrasikannya di depan aula. Kegiatan kemudian ditutup dengan penegasan materi tentang vocabulary berbasis objek di sekitar lingkungan dan penegasan materi mengenai macam-macam English greetings. 
Keesokan harinya siswa kembali berantusias mendatangi aula kantor desa Turekisa untuk melanjutkan kegiatan belajar bahasa Inggris. Materi yang dipelajari adalah Body Parts. Teknik yang digunakan dalam pembelajaran ini didominasi oleh songs and games. Melalui lagu dan permainan, siswa mempelajari parts of the body dan bagaimana melafalkannya dalam bahasa Inggris dengan baik dan benar. Setelah mempelajari body parts, topic selanjutnya adalah memperkenalkan tentang Kinds of Color dalam baahasa Inggris. Pembelajaran ini lebih bermakna dan konkrit karena siswa mempelajarinya melalui media plastic balls dengan beragam warna yang divariasikan dalam bentuk games dengan menggunakan media yang ada.

Kegiatan diakhiri dengan pemberian test akhir untuk mengetahui keterampilan bahasa Inggris siswa. Keterampilan yang ditest mencakupi empat keterampilan dasar yakni reading, speaking, writing dan listening. Hasil test keterampilan tersebut dapat dilihat pada gambar berikut:

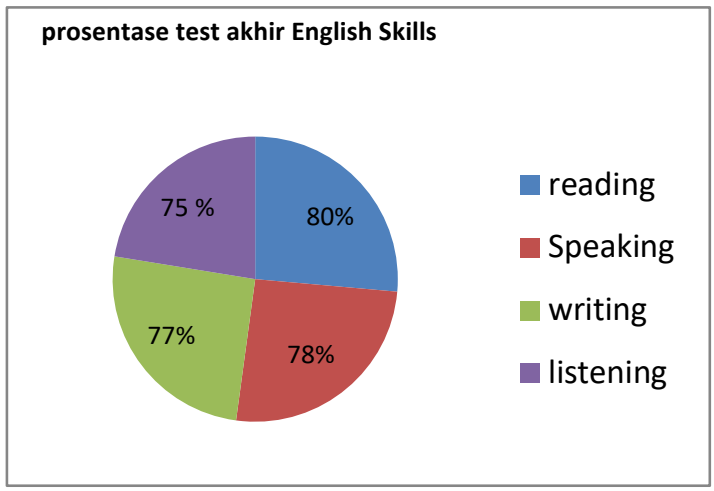

Gambar 3. Rangkuman Rata-Rata Evaluasi Akhir English Skills

Gambar di atas cukup jelas menggambarkan prosentase rata-rata nilai dari empat skills yang di test. Rata-rata nilai tertinggi adalah reading skills yakni $80 \%$, kemudian diikuti dengan speaking $78 \%$, writing $77 \%$ dan yang terendah adalah listening $75 \%$. Meskipun demikian namun rata-rata semua skill bahasa inggris yang ditest masih tergolong dalam criteria baik.

Untuk mengetahui respon siswa terhadap kegiatan pembelajaran English for the beginners melalui joyful learning ini maka dibagikan pula angket respon peserta kegiatan. Angket ini berisikan sembilan pernyataan. Pernyataan angket dan respon siswa secara keseluruhan dapat dilihat pada table berikut:
Tabel 2. Angket respon peserta kegiatan

\begin{tabular}{|c|c|c|}
\hline No & Pernyataan Angket & $\begin{array}{l}\text { Persentase } \\
(\%)\end{array}$ \\
\hline 1 & $\begin{array}{l}\text { Kegiatan } \\
\text { Pembelajaran bahasa } \\
\text { Inggris dengan Joyfull } \\
\text { Learning adalah hal } \\
\text { yang baru bagi saya }\end{array}$ & 95 \\
\hline 2 & $\begin{array}{l}\text { Saya merasa sangat } \\
\text { tertarik dengan metode } \\
\text { joyfull learning }\end{array}$ & 94 \\
\hline 3 & $\begin{array}{l}\text { Saya selalu menyimak } \\
\text { pelajaran bahasa } \\
\text { Inggris yang diberikan } \\
\text { dengan baik }\end{array}$ & 91 \\
\hline 4 & $\begin{array}{l}\text { Saya selalu menjawab } \\
\text { pertanyaan lisan dari } \\
\text { guru karena kegiatan } \\
\text { ini sangat menarik bagi } \\
\text { saya }\end{array}$ & 90 \\
\hline 5 & $\begin{array}{l}\text { Saya sangat } \\
\text { bersemangat } \\
\text { mengikuti kegiatan } \\
\text { English for kids }\end{array}$ & 93 \\
\hline 6 & $\begin{array}{l}\text { Kegiatan ini } \\
\text { memberikan } \\
\text { pengetahuan bahasa } \\
\text { inggris yang baru bagi } \\
\text { saya sebagai } \\
\text { pembelajar pemula }\end{array}$ & 100 \\
\hline 7 & $\begin{array}{l}\text { Menurut saya alokasi } \\
\text { waktu dalam kegiatan } \\
\text { ini sudah sesuai }\end{array}$ & 70 \\
\hline 8 & $\begin{array}{lr}\text { Saya merasa kegiatan } \\
\text { ini perlu dilanjutkan } \\
\text { pada } \\
\text { mendatang. }\end{array}$ & 90 \\
\hline \multirow[t]{3}{*}{9} & $\begin{array}{lr}\text { Secara umum saya } \\
\text { merasa } \\
\begin{array}{l}\text { kegiatan ini sangat } \\
\text { bermanfaat. }\end{array}\end{array}$ & 90 \\
\hline & Total & \\
\hline & Rata-Rata & $90,3 \%$ \\
\hline
\end{tabular}


Secara keseluruhan, kegiatan English for the beginners di era new normal melalui joyful learning ini memberikan dampak yang cukup signifikan bagi para peserta. Dampak tersebut terlihat secara nyata dalam hasil ratarata nilai test terhadap empat English skills yang tergolong dalam kategori baik. Hal ini di dukung dengan respon siswa (95\%) secara jujur mengatakan bahwa joyfull learning adalah metode pembelajaran yang baru bagi mereka. Meskipun baru diterapkan namun metode ini sangat menarik minat mereka untuk mempelajari bahasa Inggris (94\%), sehingga membuat mereka untuk selalu menyimak pembelajaran dengan baik (91\%) dan selalu menjawab pertanyaan lisan dari guru $(90 \%)$. Para peserta menjadi semangat mempelajari bahasa Inggris (93\%) dan 100\% memberikan pengetahuan bahasa inggris yang baru bagi siswa/i sebagai pembelajar pemula (the beginners). Namun yang disayangkan adalah alokasi waktu dalam kegiatan ini tidak sesuai dengan harapan mereka. Hal ini terlihat pada pernyataan bahwa "menurut saya alokasi waktu dalam kegiatan ini sudah sesuai" yang hanya mendapat respon (70\%). Yang mereka harapkan adalah bahwa kegiatan ini harus ada follow up nya di masa mendatang $(90 \%)$ karena secara umum mereka merasa bahwa kegiatan ini sangat bermanfaat bagi mereka (90\%). Ratarata respon siswa secara keseluruhan adalah 93\% sehingga dikategoriksn dalam kategori sangat baik.

Dengan melihat dampak yang dihasilkan melalui test di akhir kegiatan dan respon siswa yang sangat baik terhadap kegiatan ini maka dapat dikatakan bahwa joyful learning merupakan pendekatan yang efektif untuk meningkatkan minat belajar siswa. Hal ini relevan dengan temuan yang dilakukan oleh (Widyawulandari et al., 2019) yang menyimpulkan bahwa pendekatan joyful learning dapat memberikan atmosfer belajar yang menyenangkan sehingga dapat membangkitkan minat belajar siswa sekolah dasar. Hal yang sama juga ditemukan oleh (Proity, 2015) dalam penelitiannya tentang Effect of Joyful Teaching on Grade IV Students' Academic Performance in Science yang menyimpulkan bahwa joyful learning memberikan niali yang lebih tinggi jika dibandingkan dengan metode-metode konvensional.

\section{KESIMPULAN \& SARAN}

Joyful learning di era new normal yang dilaksanakan di SDI Turekisa dalam mempelajari English for the beginners memberikan dampak positif bagi para peserta kegiatan. Hal ini terlihat melalui respon siswa yang sangat positif dan hasil test terhadap empat skills bahasa Inggris siswa yang tergolong dalam kategori baik. Oleh karena itu, disarankan agar diadakan follow up dari kegiatan-kegiatan seperti ini pada masa-masa mendatang.

\section{DAFTAR PUSTAKA}

Anggoro, S., Sopandi, W., \& Sholehuddin, M. (2017). Influence of Joyful Learning on Elementary School Students'Attitudes Toward Science. Series: Journal of Physics: Conf. Series 812 (2017) 012001, 755(1). https://doi.org/10.1088/17426596/755/1/011001

Cahapay, M. B. (2020). Rethinking Education in the New Normal Post-COVID-19 Era: A Curriculum Studies Perspective. Aquademia, $\quad 4(2), \quad$ ep20018. https://doi.org/10.29333/aquademia/8315

Crawford, J., Butler-henderson, K., Rudolph, J., Malkawi, B., Glowatz, M., Magni, P. A., \& Lam, S. (2020). COVID-19: 20 countries' higher education intra-period digital pedagogy responses. Journal of Applied Learning \& Teaching, 3(1). https://doi.org/10.37074/jalt.2020.3.1.7

Fisher, B. M. E., Stockbridge, K., Dorner, M., Evensen, C. A., Maghzi, K., Pearson, H., \& Cuddy, E. (2015). Mapping Joyful Teaching and Learning: Multiple Perspectives on the Active, Collaborative Learning Environment Mapping Joyful Teaching and Learning: 26(4), 23-26. https://www.academia.edu/25661815/Ma pping_Joyful_Teaching_and_Learning Multiple_Perspectives_on_the_Active_C ollaborative_Learning_Environment

Hasan, A., Othman, Z., \& Mohd Majzub, R. (2015). Using Active, Creative, Effective and Joyful (ACEJ) Learning Strategies toward English Achievement and their Behavioural Changes among Primary School Students. Mediterranean Journal of Social Sciences, November. https://doi.org/10.5901/mjss.2015.v6n6p4 55 
Karalis, T. (2020). Planning and evaluation during educational disruption: Lessons learned from Covid-19 pandemic for treatment of emergencies in education. European Journal of Education Studies, 7(4), 2020. https://doi.org/10.5281/zenodo.3789022

Nurhadi, A. (2012). Teaching English To Young Learners ( Pengajaran Bahasa Inggris Pada Anak Usia Dini ). Educate, 1(1), 1-4. https://www.academia.edu/7037107/TEA CHING_ENGLISH_TO_YOUNG_LEA RNERS

Pali, A., \& Ota, M. K. (2020). Pendampingan Kegiatan Fun With English Pada Serikat Anak Misioner (SEKAMI) Stasi St. Keusukupan Agung Ende, Flores, NTT. SELAPARANG.Jurnal Pengabdian Masyarakat Berkemajuan, 4(November), 278-283.

https://doi.org/https://doi.org/10.31764/jp mb.v4i1.2884

Proity, S. H. (2015). Effect of Joyful Teaching on Grade IV Students " Academic Performance in Science. International Journal of Science and Research (IJSR), 4(10), 1232-1240.

Pujaningsih, Damayanti, A. (2020). Inovasi dan Transformasi Pendidikan Bermakna di Era New Normal. In E. Herwin, Kusumawardani, Erma, Nurmalasari, Y., Purwandari (Ed.), Inovasi Pembelajaran Untuk Peserta Didik Berkebutuhan Khusus di Masa Pandemi (pp. 41-56).

Sanatun A, Nurul, Sulisworo, D. (2017). Implementasi Metode Drill and Practise Secara Kelompok Untuk Peningkatan Prestasi Belajar. Unnes Phisics Education Journal, August. https://www.researchgate.net/publication/ 318982302_IMPLEMENTASI_METOD E_DRILL_AND_PRACTICE_SECARA KELOMPOK_ÜNTUK_PENINGKAT $\bar{A} N$ PRESTASI BELAJAR/link/598940 fe 45851560584 fea 0 c/download

Tria, J. Z. (2020). The COVID-19 Pandemic through the Lens of Education in the Philippines: The New Normal. International Journal of Pedagogical Development and Lifelong Learning, 1(1), ep2001. https://doi.org/10.30935/ijpdl1/8311

Widyawulandari, R., -, S., \& Indriayu, M. (2019). Implementation of Joyful Learning Approach in Providing Learning Motivation for Elementary
School Student. 277(Steach 2018), 54-58. https://doi.org/10.2991/steach-18.2019.12

Wijoyo, H., \& Indrawan, I. (2020). Model Pembelajaran Menyongsong New Era Normal Pada Lembaga Paud Di Riau. JS (Jurnal Sekolah) Universitas Negeri Medan, 4(3), 205-212. https://doi.org/https://doi.org/10.24114/js. v4i3.18526 